\title{
Effect of Tillage Depth System and Intercropping Patterns on Solid and Intercropped Soybean with Maize. \\ Sheha, A. M. ${ }^{1}$ and G. Gh. Radwan ${ }^{2}$ \\ ${ }^{1}$ Crop Intensification Res Department, Field Crops Res. Inst., A.R.C, Giza, Egypt \\ ${ }^{2}$ Agricultural Engineering Res. Inst., A.R.C, Giza, Egypt

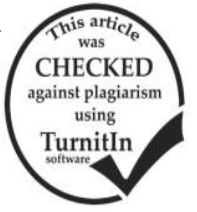

\section{ABSTRACT}

Two field experiments were carried out in Gemmeiza Research Station during the two summer successive seasons 2013 and 2014 to investigate the effect of three soil tillage depths i.e. 15, 20 and $25 \mathrm{~cm}$ and three intercropping patterns i.e. P1-100\% maize (single cross 128$)+50 \%$ soybean (variety Giza 111$)$ in ridges $(0.70 \mathrm{~m}$ in width) $\mathrm{P} 2-100 \%$ maize $+50 \%$ soybean in beds $(1.40 \mathrm{~m}$ in width) and soybean was intercropped with maize at the two rows on bed back, whereas maize was planted at both sides of the bed and P3- Pure stands of maize and soybean were planted as recommended for each crop. The experiment was laid out in a strep plot design in three replicates. Results could be summarized as follows: All characters of maize was significant by affected increasing soil tillage depth from 15 up to $20 \mathrm{~cm}$ depth except, plant height in first season. On the other hand, maize grain yield recorded the highest value with tillage depth at $20 \mathrm{~cm}$ in both seasons. Maize pure stand recorded the highest values of all studied characters followed by planting in beds and the lowest values were obtained, when maize grown in ridges in both seasons, except, plant height behaved opposite trend of these characters. indicated that plant height in the second season, No. of kernels, ear weight ${ }^{-1}, 100$-kernel weight in the first season and maize grain yield $\mathrm{fad}^{-1}$ in both seasons were significantly affected by interaction between plowing depth and intercropping patterns. Also, all soybean characters were significantly affected by tillage systems in both seasons, where, tillage depth at $20 \mathrm{~cm}$ gave the highest values, followed by at $25 \mathrm{~cm}$ While, $15 \mathrm{~cm}$ depth gave the lowest values in both seasons. Whereas soybean pure stand recorded the highest values of yield in both seasons, followed intercropping $100 \%+50 \%$ soybean on the beds in both seasons. The found that 100 -seed weight and seed yield $\mathrm{fad}^{-1}$ in both seasons were significantly affected by the interaction between different tillage depth and intercropping patterns. Soil tillage depth at $20 \mathrm{~cm}$ and intercropping pattern (100\% maize $+50 \%$ soybean) on beds recorded the highest values for LER (1.34) and LEC (0.43) in the combined analysis, which showed that intercropping had better grain yield performance when compared to sole cropping. All intercropping patterns were grown in different depths were positive for total income comparative to maize pure stand in combined analysis of both seasons. The highest total income and MAI were achieved with plowing depth at $20 \mathrm{~cm}$ in beds (8855.96and 2247.03 L.E. fad ${ }^{-1}$ ) and the lowest value was showed with plough at $25 \mathrm{~cm}$ in ridge (6426.63 and 126.01L.E.fad). Growing maize and soybean with plowing depth at $20 \mathrm{~cm}$ increased total income by 10.26 and $10.70 \%$, while MAI increased by 0.88 and $28.80 \%$ compared with plowing depth 15 and 25 respectively. It could be concluded that tillage at $20 \mathrm{~cm}$ depth and intercropping pattern $(100 \%+50 \%)$ maize/soybean planted in beds to obtain the best land usage and total income.

Keywords: Intercropping, tillage depth system, maize, Soya bean.

\section{INTRODUCTION}

Tillage will ensure the adequate moisture and air quantity needed for plant. In addition, the seeded should be as free as possible from weeds and applied fertilizer be incorporated eventually with the soil. So, before sowing seed sit is necessary prepare a suitable seeded for seed germination Abo-Habaga (1992) concluded that decreasing the percentage of less than $(0>50 \mathrm{~mm})$ in the seeded increased the main distance between adjacent seed in raw for a given number of seed per unit area and then the crop yield was increased. Sherif et al. (1995) indicated that tillage treatments significantly affected plant height, ear length, stem diameter, ear wt, wt. of grains ear ${ }^{-1}$, grain yield per plant, 100-grain wt. and grain yield fad ${ }^{-1}$. Except number of rows ear ${ }^{-1}$ Sahar Sherif et al. (2006) indicated that using chisel plough 3 passes decreased the value of mean weight diameter by $33.0 \%, 27.92 \%$ and $31.8 \%$ as compared with chisel plough 2 passes for 10,15 and $20 \mathrm{~cm}$ depth, respectively. They added that yield and quality of maize and soybean were significantly increased by using tillage with chisel plough 3 passes either in pure stands as intercrop combination. Ahadiyat and Ranamukhaarachchi (2008) studied three tillage methods (no-conventional and depth tillage) and four cropping patterns. They found that conventional and depth tillage increased yield components of maize compared with no-tillage, but grain yield remained unchanged among cropping patterns.

Hussein et al. (2007) investigated depth of plowing on growth, yield and its components of corn. They found that plant heights leaf area index, number of grains ear ${ }^{-1}$, wt. of 100-grain and grain yield fad ${ }^{-1}$ significantly affected by plowing depth. Also, they added that increasing of plowing depth $(0-40 \mathrm{~cm})$ increased the yield of grain. Yugi et al. (2011) found that lateral root distance, root dry wt. and dry biomass were greater in maize intercropped than sole maize in all tillage methods. There was insignificant effected on maize grain yield due to tillage and maize intercropped.

Abed Al-Karhi and Ali (2014) reported that conventional tillage led to a significant increase in all quantities of growth and yield of sorghum and grains yield of mung bean compared minimum tillage and zero-tillage. They added that LERs were increased by conventional tillage than other tillage treatments.

Intercropping, is one type of a multiple cropping system. It is recommended to be used in many parts of the world for food or fibers productions, because of its overall high productivity, effective control of pests and diseases, good ecological services and economic profitability. In an intercropping system, there are often two or more crop species grown in the same field for a certain period of time, even though the crops are not necessarily sown or harvested simultaneously (Thierfelder et al., 2012 and $\mathrm{Wu}$ and BZ 2014). Many investigators studied the effect of intercropping of maize with soybean. El-Douby et al. (1996) concluded that the highest maize grain yield was obtained when (4:2) soybean/ maize intercropping applied. Whereas, the highest soybean yield was produced with (2 maizes:4 soybean) maize /soybean. They added that intercropping increased LER values by 19 and $23 \%$ as compared maize alone the first and second seasons, respectively. El-Douby and Allam (2001) found that growth, ear characters and grain yield $\mathrm{fad}^{-1}$, of maize were reduced significantly compared with its pure stand. LER 
and RCC were increased in all intercropping patterns. Fathy et al. (2008) found that yield and its components of Giza 35 and 111 soybean varieties were reduced by intercropping with maize compared with its pure stands. Meanwhile the reduction in grain yield $\mathrm{fad}^{-1}$ of maize valued to 19 and $26.8 \%$ than its pure stand. They added that LERs were 1.24 and 1.37 (maize + Giza 35) and 1.12 and 1.12 (maize + Giza 111) in the first and second seasons, respectively. Lamloum and Ewis (2015) reveled that the highest maize grain yield was obtained, when maize was planted on raised-bed, while soybean yield was obtained, when soybean was grown in (2:4) maize/soybean. They added that the maximum of LER (1.53 and 1.48) and RCC (12.77 and 9.38) were observed with raised-beds. The net return showed that intercropping soybean with maize in all intercropping patterns were higher compared with solid maize or solid soybean.

The aim of this study was to obtain the best land usage and total income by applying the best tillage depth and intercropping pattern.

\section{MATERIALS AND METHODS}

Two field experiments were carried out at Gemmeiza Agricultural Research station, El-Gharbia governorate, Egypt during 2013 and 2014 seasons to investigate the effect of soil tillage depth and some intercropping patterns for soybean with maize on yield and yield components of both crops. A strip - plot design with three replicates was used, the main strip were allocated for three soil tillage treatments, whereas the sub - strip were devoted for intercropping patterns. The sub-plot area was $21 \mathrm{~m}^{2}(0.7 \times 3.0 \mathrm{~m} \times 10$ ridges or $(1.4 \mathrm{~m} \times 5$ beds $)$. The treatments were as follows: Soil tillage depth (the main strip): - Chisel plough at 15,20 and $25 \mathrm{~cm}$ (D1, D2 and D3).

Intercropping patterns (the sub strip): -

P1- $100 \%$ maize (variety single cross 128$)+50 \%$ soybean (variety Giza 111$)$ in ridges $(0.70 \mathrm{~m}$ in width) and soybean were intercropped with maize at the other side of the ridge, maize was planted at $60 \mathrm{~cm}$ between hills and thinned to two plants hill ${ }^{-1}$, whereas Soybean was thinned to two plants hill ${ }^{-1}$ with distance of $20 \mathrm{~cm}$ between hills.

P2- $100 \%$ maize $+50 \%$ soybean in beds $(1.40 \mathrm{~m}$ in width) and maize was planted on both sides of the bed at $60 \mathrm{~cm}$ between hills and thinned to two plants/hill. Whereas, soybean was planted in two rows on top at $30 \mathrm{~cm}$ between rows and thinned to two plants hill ${ }^{-1}$ with distance of $20 \mathrm{~cm}$ between hills.

P3- Pure stands of maize and soybean were planted as recommended for each crop, maize was planted at 30 $\mathrm{cm}$ between hills and thinned to one plant hill ${ }^{-1}$ and soybean was planted at both sides of the ridge and thinned to two plants hill ${ }^{-1}$ with distance of $20 \mathrm{~cm}$ between hills.

Before starting the experiments, physical soil analysis was done where the soil was clay loam in texture had an average $\mathrm{pH}$ value of $7.5 ; 1.3 \%$ organic matter and had 27, 10 and 337 ppm available N, P and K, respectively (averaged over the two seasons for the depth $30 \mathrm{~cm}$ of soil depth).

Each plot was fertilized by calcium superphosphate $\left(15.5 \% \mathrm{P}_{2} \mathrm{O}_{5)}\right.$ at a rate of $150 \mathrm{~kg} \mathrm{fad}^{-1}$ which was applied during land preparation. Potassium sulphate $\left(48 \% \mathrm{~K}_{2} \mathrm{O}\right)$ before the first and second irrigations at a rate of $50 \mathrm{~kg} \mathrm{fad}^{-}$ ${ }^{1}$ Nitrogen fertilizer as ammonium nitrate $(33.5 \% \mathrm{~N})$ was applied at a rate of $120 \mathrm{~kg} \mathrm{~N}$ fad $^{-1}$. in equal doses at the first and second irrigations. All agricultural practices as recommended were produced in both seasons,

The preceding winter crop was wheat (Triticum aestivum L.) in the two seasons. Soybean was sown on May $20^{\text {th }}$ and $24^{\text {th }}$ through 2013 and 2014 seasons, respectively. Maize was sown on June $7^{\text {th }}$ and $9^{\text {th }}$ through 2013 and 2014 seasons, respectively. The harvest in soybean in the first week and maize in second week in September, respectively. Maize was harvested at physiological maturity while soybean was harvested when the first pod of the plants fully matured. Kernels and seeds were weighted and adjusted to constant moisture of $15.5 \%$ and $12 \%$ for both components i.e. cereal and legume crop components respectively and ten plants were taken at random from each sub-plot to estimate growth the following:

Maize: Plant and ear heights $(\mathrm{cm})$, No. of leaves plant ${ }^{-1}$, leaf area index(LAI), ear length and diameter $(\mathrm{cm})$, number of kernels row ${ }^{-1}$, number of rows ear ${ }^{-1}, 100$ - kernel weight $(\mathrm{g})$, ear weight $(\mathrm{g})$. Whereas grain yield $\mathrm{fad}^{-1}$ from whole sub-plot.

Soybean: Plant height $(\mathrm{cm})$, number of branches and pods plant $^{-1}, 100$ - seed weight (g), Seed and biological yields $\left(\right.$ ton $\left.\mathrm{fad}^{-1}\right)$.

A- Land use efficiency: In order to assess the land use efficiency, Total Land Equivalent Ratio (Total LER) was suggested by Monzon et al., (2014). It was determined according to do as the sum of yield relative i.e. intercrop yields relative to their solid yield. The total LER an accurate assessment of the biological efficiency of the intercropping situation, using the following equation to evaluate and compare the productivity of relay intercropping and mono cropping:

Total LER $=($ Yab $/$ Yaa $)+($ Yba $/$ Ybb $)$.

Where, Yaa and $\mathrm{Ybb}$ are yields as sole crops of component a (Maize) and component $b$ (soybean) and $\mathrm{Yab}$ and $\mathrm{Yba}$ are yields as intercrops of $\mathrm{a}$ and $\mathrm{b}$, respectively. Values of total LER greater than 1.0 are considered advantages. While, values of total LER less than 1.0 are considered disadvantages.

\section{B- Land equivalent coefficient (LEC):}

A measure of interaction concerned with the strength of relationship was calculated thus, $\mathrm{LEC}=\mathrm{La} \times \mathrm{Lb}$. Where, $\mathrm{La}=$ partial LER of main crop and $\mathrm{Lb}=$ partial LER of intercrop (Aditiloye et al., 1983), for a two- crop mixture the minimum expected productivity coefficient (PC) is $25 \%$ that is a yield advantage is obtained if LEC exceeds 0.25 .

\section{C- Relative crowding coefficient (RCC):}

This parameter was proposed according to De-wit (1960) it assumes that mixture treatment forms are placement series. Each series has its own coefficient (K) which gives a measure to indicate that series has produced more, less or equal yield to that expected. Relative crowding coefficient (RCC) was determined according to the following formula: for species (a) in mixture with species (b). 
$\mathbf{K a b}=\frac{Y a b \times Z b a}{(y a a-y a b) \times z a b} \quad \mathbf{K b a}=\frac{Y b a \times Z a b}{(Y a a-y b a) \times Z b a}$

Where: Zab is sown proportion of species a (in a mixture with $b$ ) and $\mathrm{Zba}$ is sown proportion of species $b$ (in a mixture with a).

If a species has a coefficient less than, equal to, or greater than one, means it has produced less yield, the same yield, or more yield than the "expected", respectively.

The component crop with the higher coefficient is the dominant one. to determine if there is a yield advantage of mixing, the product of the coefficient is formed by multiplying $\mathrm{Kab} X \mathrm{Kba} \quad$ If $\mathrm{K}>1$, there is yield advantage, If $\mathrm{K}<1$ there a yield disadvantage.

\section{D-Economic evaluation:}

Gross return from each treatment was calculated in Egyptian pounds (LE). One ardab of maize $(140 \mathrm{~kg})=317$ LE and one ton of soybean seed $=4480$ LE. In 2013 and 2014, the average Prices were taken from the Ministry of Agriculture and Land Reclamation, Economic Affairs Sector, Agricultural Statistics of 2013 and 2014 years.

E- Monetary advantage index (MAI): It suggests that the economic assessment should be in terms of the value of land saved. This could probably be assessed on the basis of the rentable value of this land.MAI was calculated according to formula, suggested by Willey (1979).

MAI $=[$ Economic value of combined intercrops $\times($ LER-1) ]LER ${ }^{-1}$

Statistical analysis: the obtained data were statistically analyzed according to Steel et al. (1997), and least significant difference LSD was used to separate the treatment means at $5 \%$ level of significance.

\section{RESULTS AND DISCUSSION}

\section{First: Maize}

A- Soil tillage depth effect:

Results presented in Tables 1 and 2 revealed that all studied characters i.e. No. of leaves plant ${ }^{-1}$, Leaf area Index (LAI), ear length and diameter $(\mathrm{cm})$, number of kernels row $^{-1}$, ear weight $(\mathrm{g}), 100$-kernel weight and maize yield $\left(\operatorname{ardab} \mathrm{fad}^{-1}\right)$ of maize were significantly affected by plowing depth in both seasons except, plant height and No. of rows ear ${ }^{-1}$ were significantly affected in one season out of two and ear height was not significantly affected in both seasons.

Plant height of maize recorded the highest values where maize was planted at $15 \mathrm{~cm}$ depth followed by at 20 whereas the lowest value was showed with $25 \mathrm{~cm}$ depth in $2^{\text {nd }}$ season. This result may be due to increase the depth gave the big aggregates at 15 or $20 \mathrm{~cm}$ depth than $25 \mathrm{~cm}$ as well as tillage at deep depth increased the percentage of small soil colds size (less $50 \mathrm{~mm}$ ) and the value of meat weight diameter (MWD) was decreased by plowing depth (Sherif et al., 2006 and Abed Al-Karhi and Ali (2014) plowing depth at $20 \mathrm{~cm}$ was recorded the highest values for other growth characters i.e ear height, No. of leaves plant ${ }^{-1}$ and leaf area index (LAI), while, $15 \mathrm{~cm}$ depth ranked second whereas, $25 \mathrm{~cm}$ showed the lowest values for aforementioned traits in both seasons. This result may be due to the total root length was significantly influenced by tillage depth and the tillage practices conventional tillage had greatest deep tillage intermediate and there was a decrease in root length density as the soil depth increased (Ahadiyat and Ranamukhaarachchi, 2008 and Dube et al., 2014).

Table 1. Plant and ear heights $(\mathrm{cm})$, no. of leaves plant ${ }^{-1}$, leaf area index(LAI), ear length and diameter (cm), no. of rows ear ${ }^{-1}$ of maize as affected by soil tillage depth and intercropping patterns in both seasons.

\begin{tabular}{|c|c|c|c|c|c|c|c|c|c|c|c|c|c|c|}
\hline \multirow{2}{*}{$\begin{array}{l}\text { Main effects } \\
\text { and interaction }\end{array}$} & \multicolumn{2}{|c|}{$\begin{array}{l}\text { Plant height } \\
\text { (cm) }\end{array}$} & \multicolumn{2}{|c|}{$\begin{array}{l}\text { Ear height } \\
\text { (cm) }\end{array}$} & \multicolumn{2}{|c|}{$\begin{array}{c}\text { No. of leaves } \\
\text { plant }^{-1}\end{array}$} & \multicolumn{2}{|c|}{$\begin{array}{l}\text { Leaf area } \\
\text { Index }\end{array}$} & \multicolumn{2}{|c|}{$\begin{array}{l}\text { Ear length } \\
\text { (cm) }\end{array}$} & \multicolumn{2}{|c|}{$\begin{array}{c}\text { Ear } \\
\text { diameter }(\mathrm{cm})\end{array}$} & \multicolumn{2}{|c|}{ No. of rows ear ${ }^{-1}$} \\
\hline & 2013 & 2014 & 2013 & 2014 & 2013 & 2013 & 2013 & 2014 & 2013 & 2014 & 2013 & 2014 & 2013 & 2014 \\
\hline \multicolumn{15}{|c|}{ Soil tillage depth } \\
\hline $15 \mathrm{~cm}(\mathrm{D} 1)$ & 245.67 & 247.00 & 138 & 132.23 & 15.28 & 17.01 & 5.19 & 4.13 & 20.08 & 19.74 & 4.30 & 4.34 & 13.84 & 13.91 \\
\hline $\mathrm{cm}(\mathrm{D} 2)$ & 4.91 & 240.77 & 140.12 & 134.67 & 16.67 & 18.21 & 5.70 & 4.47 & 21.89 & 21.64 & 4.52 & 4.48 & 4.41 & 14.07 \\
\hline $25 \mathrm{~cm}(\mathrm{D} 3)$ & 242.12 & 224.22 & 137.20 & 126.67 & 14.20 & 14.76 & 4.65 & 3.92 & 19.17 & 18.57 & 4.02 & 4.11 & 13.02 & 13.61 \\
\hline Test & N.S & * & N.S & N.S & $*$ & * & $*$ & $*$ & * & * & $*$ & $*$ & $*$ & N.S \\
\hline $\mathrm{LSD}_{0.05}$ & - & 3.87 & - & - & 0.26 & 0.48 & 0.39 & 0.28 & 0.43 & 1.71 & 0.17 & 0.17 & 0.31 & \\
\hline \multicolumn{15}{|c|}{ Intercropping patterns } \\
\hline Pattern(P1) & 251.56 & 245.11 & 136.68 & 126.22 & 15.13 & 15.97 & 4.97 & 4.03 & 19.87 & 19.75 & 4.15 & 4.14 & 12.8 & 13.19 \\
\hline Pattern(P2) & 241.57 & 237.56 & 138 & 129.22 & 15.34 & 16.61 & 5.19 & 4.15 & 20.32 & 19.89 & 4.29 & 4.31 & 13.81 & 13.92 \\
\hline Pattern(P3) & 239.57 & 229.33 & 140.64 & 138.12 & 15.66 & 17.40 & 5.37 & 4.35 & 20.94 & 20.30 & 4.40 & 4.48 & 14.63 & 14.48 \\
\hline F Test & $*$ & $*$ & $*$ & $*$ & $*$ & $*$ & $*$ & $*$ & $*$ & N.S & $*$ & $*$ & $*$ & $*$ \\
\hline $\operatorname{LSD}_{0.05}$ & 5.61 & 2.87 & 0.62 & 3.94 & 0.27 & 0.30 & 0.31 & 0.21 & 0.38 & N.S & 0.12 & 0.12 & 0.4 & 0.31 \\
\hline Interaction $(\mathrm{D} \times \mathrm{P})$ : & N.S & $*$ & N.S & N.S & N.S & N.S & N.S & N.S & N.S & N.S & N.S & N.S & N.S & N.S \\
\hline
\end{tabular}

Whereas: Soil tillage depth 15, 20 and $25 \mathrm{~cm}(\mathrm{D} 1, \mathrm{D2}$ and D3)

Pattern (P1) refers to $100 \%$ maize $+50 \%$ soybean in ridges $(0.70 \mathrm{~m}$ in width) and soybean were intercropped with maize at the other side of the ridge, Pattern (P2) refers to $100 \%$ maize $+50 \%$ soybean in beds $(1.40 \mathrm{~m}$ in width) and maize was intercropped at the both sides of the bed, Pattern (P3) refers to pure stands of maize.

Ear characters, i.e., ear length and diameter $(\mathrm{cm})$, No. of rows ear ${ }^{-1}$, No. of kernels/row, ear weight ${ }^{-1}(\mathrm{gm})$ and 100-kernel weight (gm) behaved the same trend of other growth characters as shown in Tables 1 and 2 . Where, revealed that plowing at $20 \mathrm{~cm}$ depth was superior to other plowing depths followed by 15 and $25 \mathrm{~cm}$ indicated the lowest values for these characters in both seasons. These results may be due to the reflecting of other growth characters. Similar results were obtained by Hussein et al. (2007) and Al-jabori and Al-jabori (2015). The grain yield of maize fad $^{-1}$ grown in plowing $20 \mathrm{~cm}$ depth gave the highest yield (20.12 and 19.94) followed by $15 \mathrm{~cm}$ (17.95 and 17.85) and the lowest value was showed with $25 \mathrm{~cm}$ (17.57 and $16.64 \mathrm{ardab} \mathrm{fad}^{-1}$.) in the first and 
second seasons, respectively. There was a decrease in root length density as the soil depth increased. These results were related to growth were obtained by Sherif et al. (1995), Abed $\mathrm{Al}$-Karhi and Ali (2014) and Al-jabori and Al-jabori (2015).

\section{B- Intercropping patterns effect:}

Results presented in Tables 1 and 2 indicated that some growth, yield and yield components of maize were significantly affected by intercropping patterns in both seasons except ear length in second season (2014). There were significant differences $(\mathrm{P}<0.05)$ in maize traits. The intercropping pattern $(100 \%$ maize $+50 \%$ soybean $)$ in

Table 2. Number of kernels $\mathrm{row}^{-1}$, ear kernels weight (g), 100-kernel weight and maize yield $\left(\operatorname{ardab}^{-1}\right) \mathrm{as}^{-1}$ affected by soil tillage depth and intercropping patterns in both seasons.

\begin{tabular}{|c|c|c|c|c|c|c|c|c|}
\hline \multirow{2}{*}{$\begin{array}{l}\text { Main effects } \\
\text { and interaction }\end{array}$} & \multicolumn{2}{|c|}{ No. of kernels row ${ }^{-1}$} & \multicolumn{2}{|c|}{ Ear weight (g) } & \multicolumn{2}{|c|}{100 -kernel weight (g) } & \multicolumn{2}{|c|}{ Maize yield ( $\left.\operatorname{ardab~fad}^{-1}\right)$} \\
\hline & 2013 & 2014 & 2013 & 2014 & 2013 & 2014 & 2013 & 2014 \\
\hline \multicolumn{9}{|l|}{ Soil tillage depth } \\
\hline $15 \mathrm{~cm}(\mathrm{D} 1)$ & 38.68 & 38.55 & 220.42 & 215.03 & 34.45 & 32.59 & 17.95 & 17.85 \\
\hline $20 \mathrm{~cm}(\mathrm{D} 2)$ & 40.79 & 40.77 & 227.05 & 219.84 & 36.63 & 33.88 & 20.12 & 19.94 \\
\hline $25 \mathrm{~cm}(\mathrm{D} 3)$ & 37.31 & 37.53 & 207.49 & 222.36 & 30.76 & 30.90 & 17.57 & 16.64 \\
\hline F test & $*$ & $*$ & $*$ & $*$ & $*$ & $*$ & $*$ & $*$ \\
\hline $\mathrm{LSD}_{0.05}$ & 0.61 & 0.24 & 2.89 & 2.34 & 0.63 & 0.78 & 1.53 & 1.11 \\
\hline \multicolumn{9}{|c|}{ Intercropping patterns } \\
\hline Pattern(P1) & 37.53 & 35.89 & 211.89 & 218.11 & 32.68 & 30.74 & 15.20 & 16.68 \\
\hline Pattern(P2) & 38.28 & 39.63 & 219.15 & 209.44 & 33.79 & 32.52 & 17.82 & 17.71 \\
\hline Pattern(P3) & 40.97 & 41.34 & 223.91 & 229.68 & 35.37 & 34.11 & 22.62 & 20.04 \\
\hline F test & * & $*$ & $*$ & $*$ & * & $*$ & * & $*$ \\
\hline $\operatorname{LSD}_{0.05}$ & 0.60 & 0.49 & 1.87 & 1.79 & 0.42 & 0.62 & 0.74 & 1.03 \\
\hline Interaction $(\mathrm{D} \times \mathrm{P})$ : & $*$ & N.S & $*$ & N.S & $*$ & N.S & $*$ & $*$ \\
\hline
\end{tabular}

Whereas: Soil tillage depth 15, 20 and $25 \mathrm{~cm}(\mathrm{D} 1, \mathrm{D2}$ and D3)

Pattern (P1) refers to $100 \%$ maize $+50 \%$ soybean in ridges $(0.70 \mathrm{~m}$ in width) and soybean were intercropped with maize at the other side of the ridge, Pattern (P2) refers to $100 \%$ maize $+50 \%$ soybean in beds $(1.40 \mathrm{~m}$ in width) and maize was intercropped at the both sides of the bed, Pattern (P3) refers to pure stands of maize.

Some growth characters i.e ear length $(\mathrm{cm})$, No. of leaves plant ${ }^{-1}$ and leaf area index (LAI) were significantly affected by intercropping patterns in both seasons (Table 1). It is quite evident that planting maize as a pure stand significantly increased in aforementioned traits in both seasons followed by intercropping patterns on beds and ridges, respectively. The significant decrease in aforementioned traits under intercropping patterns than pure stand of maize is mainly due to the increase in inter specific competition between maize and soybean plants for light and nutrient resources. Similar results were reported by ElDouby and Allam (2001).

Yield attributes characteristics of maize, i.e. ear length and diameter, No. of rows ear ${ }^{-1}$, No. of kernels/row and 100-kernel weight were significantly affected by intercropping patterns in both seasons (Tables 1 and 2). It is clear from results that intercropping 50\% soybean of its pure stand with $100 \%$ maize in ridges or beds decreased these traits compared maize pure stand. These results in yield attributes are expected as a result of trend some growth characters, i.e. ear height, No. of leaves plant ${ }^{-1}$ and leaf area index (LAI). Similar results were obtained by El-Douby (1992) and Sahar Sherif et al. (2006).

Maize grain yield $\mathrm{fad}^{-1}$ behaved the same trend of yield attributes in both seasons as shown in Table 2. Maize grain yield $\mathrm{fad}^{-1}$ of pure stand was superior to other intercropping patterns either in ridges or in beds. The decrease in maize grain yield were $32.80 \%, 21.22 \%$ for intercropping patterns $100 \%$ maize $+50 \%$ soybean in ridges (P1) and $100 \%+50 \%$ in bed (P2) in the first season, respectively; and $16.76 \%$ and $11.62 \%$ in the second season ridges, maize achieved the highest plant height with mean $(251.56$ and $245.11 \mathrm{~cm})$ followed by intercropping pattern $(100 \%+50 \%)$ in beds $(241.58$ and $237.56 \mathrm{~cm})$ and simultaneously maize alone gave the lowest value $(239.57$ and $229.33 \mathrm{~cm}$ ) in the first and this result may be due to the effect of intra -specific competition among maize plants and Inter-specific competition between maize and soybean plants either in ridges or in beds with $50 \%$ soybean plants. Opposite results were obtained with Lamloum and Ewis (2015).

compared with maize grain yield in pure stand. Similar results were obtained with El-Douby et al. (1996) and Fathy et al. (2008).

\section{C- Interaction effect:}

Results presented in Table 3 revealed that plant height in the second season, No. of kernels, ear weight ${ }^{-1}$, 100 -kernel weight in the first season and maize grain yield fad $^{-1}$ in both seasons were significantly affected by interaction between plowing depth and intercropping patterns.

Plant height recorded the highest value was maize soil tillage depth at $15 \mathrm{~cm}$ and planting 100\% maize $+50 \%$ soybean in ridges (D1X P1). On the other hand, the lowest value was showed with tillage at $25 \mathrm{~cm}$ depth and maize planting alone (D3X P3). With respect to No. of kernels/row, ear weight ${ }^{-1}, 100$-kernel weight and maize grain yield $\mathrm{fad}^{-1}$ the highest values of aforementioned traits were recorded where soil tillage depth at $20 \mathrm{~cm}$ with maize alone (D2 X P3). Whereas, these characteristics indicated the lowest values when soil tillage at $25 \mathrm{~cm}$ depth with intercropping pattern $(100 \%$ maize $+50 \%$ soybean $)$ in ridges (D3X P1).

\section{Second: Soybean}

\section{A-Soil tillage depth effect}

Results in Table 4 show that soybean some growth, yield and yield components characteristics were significantly affected by ploughing depth in both seasons. Results indicated that ploughing at $20 \mathrm{~cm}$ (D2) depth gave the highest values followed by $25 \mathrm{~cm}$ (D3) and simultaneously ploughing $15 \mathrm{~cm}$ (D1) showed the lowest values. Their result is completely true for each of plant height, No. of 
branches and pods plant ${ }^{-1}, 100$-seed weight, seed and biological yield $\mathrm{fad}^{-1}$. in both seasons. On the other hand, results indicated the soybean seed yield fad $^{-1}$ decreased by $39.65,32.65$ and $38.01 \%$ when tillage depths at 15,20 and $25 \mathrm{~cm}$, respectively in the first season compared with soybean pure stand and were $45.49,33.12$ and 34.42 in the second seasons. It is evident that higher yield of soybean was obtained when soybean plants were grown under ploughing, depth at $20 \mathrm{~cm}$ (D2). Results revealed that biological yield fad $^{-1}$ was related to seed yield and behaved the same trend of soybean seed yield in both seasons. These results are agreeing with those obtained by El-Sayed (1983), Sahar Sherif et al. (2006) and Hussein et al. (2007).

Table 3. Influence of the interaction between soil tillage depth and intercropping patterns of Maize in both seasons.

\begin{tabular}{|c|c|c|c|c|c|c|c|c|c|c|c|c|c|c|c|c|c|c|}
\hline \multirow{3}{*}{$\begin{array}{l}\text { Soil depth } \\
\text { Tillage }\end{array}$} & \multirow{2}{*}{\multicolumn{3}{|c|}{$\begin{array}{c}\text { Plant height } \\
\text { (cm) } \\
2014\end{array}$}} & \multirow{2}{*}{\multicolumn{3}{|c|}{$\begin{array}{l}\text { No. of } \\
\text { kernels row }^{-1} \\
2013\end{array}$}} & \multirow{2}{*}{\multicolumn{3}{|c|}{$\begin{array}{c}\text { Intercropping } \\
\text { Kernel weight ear }^{-1} \\
\text { (g) } \\
\mathbf{2 0 1 3}\end{array}$}} & \multirow{2}{*}{\multicolumn{3}{|c|}{$\begin{array}{l}\text { patterns } \\
100 \text { kernel weight } \\
\text { (g) } \\
2013\end{array}$}} & \multicolumn{6}{|c|}{$\begin{array}{l}\text { Maize grain } \\
\text { ardab fad }^{-1}\end{array}$} \\
\hline & & & & & & & & & & & & & & 2013 & & & 2014 & \\
\hline & P1 & P2 & P3 & P1 & P2 & P3 & P1 & P2 & P3 & P1 & P2 & P3 & P1 & P2 & P3 & P1 & P2 & P3 \\
\hline $15 \mathrm{~cm}(\mathrm{D} 1)$ & 259.3 & 247.0 & 234.7 & 38.2 & 37.2 & 40.7 & 215.7 & 219.0 & 226.5 & 33.3 & 34.7 & 35.4 & 14.1 & 17.5 & 22.2 & 17.3 & 17.9 & 18.4 \\
\hline $20 \mathrm{~cm}$ (D2) & 248.0 & 241.0 & 233.3 & 39.0 & 41.2 & 42.1 & 221.9 & 227.2 & 232.1 & 35.6 & 36.3 & 37.9 & 17.5 & 18.3 & 24.4 & 17.9 & 19.3 & 22.6 \\
\hline $25 \mathrm{~cm}(\mathrm{D} 3)$ & 228.0 & 224.7 & 220.0 & 35.4 & 36.4 & 40.1 & 198.1 & $\begin{array}{c}211.2 \\
559\end{array}$ & 213.1 & 29.2 & 30.4 & 32.8 & 14.1 & 17.4 & 21.3 & 14.8 & 15.9 & 19.2 \\
\hline
\end{tabular}

Whereas: Soil tillage depth 15, 20 and $25 \mathrm{~cm}$ (D1, D2 and D3)

Pattern (P1) refers to $100 \%$ maize $+50 \%$ soybean in ridges $(0.70 \mathrm{~m}$ in width) and soybean were intercropped with maize at the other side of the ridge, Pattern (P2) refers to $100 \%$ maize $+50 \%$ soybean in beds $(1.40 \mathrm{~m}$ in width) and maize was intercropped at the both sides of the bed, Pattern (P3) refers to pure stands of maize.

Table 4. Plant height, no. of branches and pods plant ${ }^{-1}, 100$-grain weight, biological and seed yields fad ${ }^{-1}$ of soybean $^{-}$ as affected by soil tillage depth and intercropping pattern in both seasons.

\begin{tabular}{|c|c|c|c|c|c|c|c|c|c|c|c|c|}
\hline \multirow[t]{2}{*}{$\begin{array}{l}\text { Main effects and } \\
\text { interaction }\end{array}$} & \multicolumn{2}{|c|}{$\begin{array}{l}\text { Plant height } \\
\text { (cm) }\end{array}$} & \multicolumn{2}{|c|}{$\begin{array}{l}\text { No. of branches } \\
\text { plant }^{-1}\end{array}$} & \multicolumn{2}{|c|}{$\begin{array}{c}\text { No. of pods } \\
\text { plant }^{-1}\end{array}$} & \multicolumn{2}{|c|}{$\begin{array}{c}\text { 100-seed } \\
\text { weight(g) }\end{array}$} & \multicolumn{2}{|c|}{$\begin{array}{l}\text { Seed yield } \\
\left(\mathrm{Kg} \mathrm{fad}^{-1}\right)\end{array}$} & \multicolumn{2}{|c|}{$\begin{array}{l}\text { Biological yield } \\
\text { (Ton fad }^{-1} \text { ) }\end{array}$} \\
\hline & 2013 & 2014 & 2013 & 2014 & 2013 & 2014 & 2013 & 2014 & 2013 & 2014 & 2013 & 2014 \\
\hline \multicolumn{13}{|c|}{ Soil tillage depth(cm) } \\
\hline $15 \mathrm{~cm}(\mathrm{D} 1)$ & 115.53 & 115.46 & 2.36 & 2.16 & 51.63 & 43.71 & 18.79 & 18.72 & 738.5 & 7751 & 4.74 & 5.42 \\
\hline $20 \mathrm{~cm}(\mathrm{D} 2)$ & 122.83 & 120.47 & 2.95 & 3.22 & 64.64 & 58.18 & 20.95 & 21.64 & 880.44 & 925.88 & 5.98 & 6.26 \\
\hline $25 \mathrm{~cm}(\mathrm{D} 3)$ & 119.24 & 118.30 & 2.68 & 2.90 & 61.01 & 45.94 & 19.86 & 20.25 & 810.00 & 907.89 & 5.57 & 5.80 \\
\hline F test & $*$ & $*$ & $*$ & $*$ & $*$ & $*$ & $*$ & $*$ & $*$ & $*$ & $*$ & $*$ \\
\hline $\mathrm{LSD}_{0.05}$ & 4.24 & 2.58 & 0.28 & 0.31 & 8.32 & 2.05 & 0.44 & 0.54 & 14.25 & 11.11 & 0.50 & 0.31 \\
\hline \multicolumn{13}{|c|}{ Intercropping pattern } \\
\hline Pattern1 & 119.27 & 118.02 & 2.22 & 2.58 & 48.26 & 42.44 & 19.13 & 19.17 & 373.3 & 417.3 & 3.72 & 3.97 \\
\hline Pattern2 & 122.78 & 121.39 & 2.65 & 2.66 & 56.20 & 46.33 & 19.28 & 20.05 & 648.33 & 707.33 & 4.53 & 5.18 \\
\hline Pattern3 & 115.56 & 114.82 & 3.11 & 3.04 & 72.83 & 59.07 & 21.20 & 21.38 & 1306.78 & 1384.43 & 7.94 & 8.33 \\
\hline F test & $*$ & $*$ & $*$ & $*$ & $*$ & $*$ & $*$ & $*$ & $*$ & $*$ & $*$ & $*$ \\
\hline $\mathrm{LSD}_{0.05}$ & 2.58 & 1.70 & 0.21 & 0.37 & 6.07 & 2.50 & 0.44 & 0.43 & 22.85 & 15.10 & 0.34 & 0.31 \\
\hline Interaction $(\mathrm{D} \times \mathrm{P})$ & N.S & $*$ & N.S & N.S & N.S & N.S & $*$ & $*$ & $*$ & $*$ & N.S & N.S \\
\hline
\end{tabular}

Whereas: Soil tillage depth 15, 20 and $25 \mathrm{~cm}(\mathrm{D} 1, \mathrm{D2}$ and D3)

Pattern(P1)refers to $100 \%$ maize $+50 \%$ soybean in ridges $(0.70 \mathrm{~m}$ in width)and soybean were intercropped with maize at the other side of the ridge, Pattern ( $\mathrm{P} 2)$ refers to $100 \%$ maize $+50 \%$ soybean in beds $(1.40 \mathrm{~m}$ in width) and maize was intercropped at the both sides of the bed,

Pattern (P3) refers to pure stands of soybean.

\section{B- Intercropping patterns effect:}

Results in Table 4 indicate significant effects on all aforementioned traits of soybean in both seasons. Results showed that growing soybean in beds with maize gave the highest values for plant height followed by intercropping patterns $100 \%$ maize $+50 \%$ soybean in ridges and the shortest plant height was showed with soybean pure stand. Soybean plants under intercropping patterns were higher than pure stands of soybean. These results may be due to sever inter specific competition between maize and soybean plants for light and nutrients. Similar results were obtained by El-Douby and Allam (2001), Fathy et al. (2008) and Lamloum and Ewis (2015).

Results present in Table 4 showed that pure stands of soybean recorded the highest values and intercropping soybean with maize as (100\% maize +50 soybean $\%)$ on beds $(\mathrm{P} 2)$ ranked the $2^{\text {nd }}$ whereas on ridges gave the lowest value. These results were true in traits of No. of branches and pods plant ${ }^{-1}, 100$-seed weight seed and biological yield $\mathrm{fad}^{-1}$ in both seasons. Results revealed that seed yield fad ${ }^{-1}$ where found achieved intercropping patterns $100 \%$ maize + $50 \%$ soybean in ridges $(\mathrm{P} 1)$ and beds( $(\mathrm{P} 2) 40.09$ and $49.61 \%$ of its pure stand, respectively in the first seasons; and 40.96 and $51.09 \%$ in the second seasons. Biological yield fad $^{-1}$ behaved the same trend of seed yield in both seasons. Biological yield was 46.85 and $57.05 \%$ in the first seasons; and 47.65 and $62.18 \%$ in the second season. Similar results were obtained by Sahar Sherif et al. (2006), Fathy et al. (2008) and Lamloum and Ewis (2015).

\section{C- Interaction effect:}

Table 5 show that plant height in the first season, 100 -seed weight and seed yield $\mathrm{fad}^{-1}$ in both seasons were significantly affected by the interaction between different tillage depth and intercropping patterns( $\mathrm{D} \times \mathrm{P})$.

Plant height of soybean recorded the highest value under tillage depth at $20 \mathrm{~cm}$ with intercropping pattern $(100 \%$ maize $+50 \%$ soybean) in beds (D2xp2) and opposite, the lowest value for this character was obtained under tillage depth at $15 \mathrm{~cm}$ with soybean solid. 
Table 5. Influenced by the interaction between soil tillage depth and intercropping pattern of soybean in both seasons.

\begin{tabular}{|c|c|c|c|c|c|c|c|c|c|c|c|c|c|c|c|}
\hline \multirow{4}{*}{$\begin{array}{l}\text { Soil tillage } \\
\text { depth }\end{array}$} & \multirow{3}{*}{\multicolumn{3}{|c|}{$\begin{array}{c}\text { Plant height cm) } \\
2014\end{array}$}} & \multicolumn{11}{|c|}{ Intercropping pattern } & \multirow[b]{4}{*}{ P3 } \\
\hline & & & & \multirow{2}{*}{\multicolumn{6}{|c|}{$2013 \begin{array}{cc}100 \text {-seed weight }(\mathrm{g}) \\
2014\end{array}$}} & \multicolumn{5}{|c|}{ Seed yield (kg fad $\left.{ }^{-1}\right)$} & \\
\hline & & & & & & & & & & & 2013 & & & 2014 & \\
\hline & P1 & P2 & P3 & P1 & $\mathbf{P 2}$ & P3 & P1 & $\mathbf{P 2}$ & P3 & P1 & $\mathbf{P 2}$ & P3 & P1 & P2 & \\
\hline $15 \mathrm{~cm}(\mathrm{D} 1)$ & 116.0 & 120.6 & 109.8 & 18.8 & 18.6 & 19.1 & 18.2 & 18.3 & 19.6 & 343.2 & 618.3 & 1254.0 & 358.3 & 642.0 & 1325.0 \\
\hline $20 \mathrm{cn}$ & 120.6 & 122.2 & 118.6 & 19.6 & 20.3 & 22.8 & 20.9 & 21.3 & 22.6 & 405.3 & 726.6 & 1359.6 & 433.0 & 766.6 & 1428.0 \\
\hline $25 \mathrm{~cm}(\mathrm{D} 3)$ & 117.5 & 121.4 & 116.0 & 19.2 & 18.9 & 21.5 & 18.40 & 20.4 & 21.9 & 373.3 & 600.0 & 1306.6 & 460.0 & 713.3 & 1400.3 \\
\hline $\mathrm{LSD}_{0.05}$ & & 3.50 & & & 0.77 & & & 0.93 & & & 39.57 & & & 26.16 & \\
\hline
\end{tabular}

Whereas: Soil tillage depth 15, 20 and $25 \mathrm{~cm}(\mathrm{D} 1, \mathrm{D2}$ and D3)

Pattern (P1) refers to $100 \%$ maize $+50 \%$ soybean in ridges $(0.70 \mathrm{~m}$ in width) and soybean were intercropped with maize at the other side of the ridge, Pattern (P2) refers to $100 \%$ maize $+50 \%$ soybean in beds $(1.40 \mathrm{~m}$ in width) and maize was intercropped at the both sides of the bed,

Pattern (P3) refers to pure stands of soybean.

Planting of soybean in pure stand under tillage at 20 $\mathrm{cm}$ (D2xP3) gave the highest value and opposite intercropping soybean by $50 \%+100 \%$ maize in ridges under tillage $15 \mathrm{~cm}$ depth (D1xP1) gave the lowest value. This is completely true of both 100 -seed wt. and seed yield $\mathrm{fad}^{-1}$. in both seasons. This result may be due to growing soybean as a pure stand was planted by $100 \%$ while under intercropping patterns was planted by $50 \%$ of its pure stand, on the other hand, decreasing the percentage of less than $50 \%$ in seeding rates increased the main distance between adjacent plants in row for a given number of seeds per unit area and then the crop yield was increased, Similar results were obtained (Abo-Habaga, 1992).

Table 6. Land equivalent ration (LER), land equivalent coefficient (LEC), relative crowding coefficient (RCC), as affected by between soil tillage depth and intercropping pattern in both seasons (2013 and 2014 ) and their combined.

\begin{tabular}{|c|c|c|c|c|c|c|c|c|c|}
\hline \multirow[b]{2}{*}{ Intercropping pattern } & \multicolumn{9}{|c|}{ Mean effect intercropping patterns } \\
\hline & 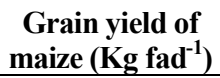 & $\begin{array}{c}\text { Seed yield of } \\
\text { soybean }\left(\mathrm{Kg} \mathrm{fad}^{1}\right)\end{array}$ & Lm & Ls & LER & LEC & $\mathbf{K m}$ & $\begin{array}{c}\text { RCC } \\
\text { Ks }\end{array}$ & $\mathbf{K}$ \\
\hline & \multicolumn{9}{|c|}{ Season 2013} \\
\hline Pure stands of maize (P3) & 3108 & ----- & 1.0 & ----- & 1.0 & 1.0 & ----- & ----- & ----- \\
\hline Pure stands of soybean (P3) & ----- & 1206.73 & ----- & 1.0 & 1.0 & 1.0 & ----- & ----- & ----- \\
\hline$(100 \%$ maize $+50 \%$ soybean on ridges $(\mathrm{P} 1)$ & 2128 & 523.89 & 0.69 & 0.29 & 0.98 & 0.42 & 1.07 & 0.82 & 0.88 \\
\hline$(100 \%$ maize $+50 \%$ soybean on beds) $(\mathrm{P} 2)$ & 2494.8 & 373.93 & 0.80 & 0.50 & 1.30 & 0.40 & 2.00 & 2.00 & 4.00 \\
\hline \multicolumn{10}{|c|}{ Season 2014} \\
\hline Pure stands of maize (P3) & 2805.6 & ---- & 1.0 & ----- & 1.0 & 1.0 & ----- & ----- & ----- \\
\hline Pure stands of soybean (P3) & ----- & 1384.43 & ------ & 1.0 & 1.0 & 1.0 & ----- & ----- & ----- \\
\hline$(100 \%$ maize $+50 \%$ soybean on ridges $)(\mathrm{P} 1)$ & 2335.2 & 417.1 & 0.83 & 0.30 & 1.13 & 0.36 & 2.45 & 0.88 & 2.16 \\
\hline$(100 \%$ maize $+50 \%$ soybean on beds) (P2) & 2479.4 & 707.33 & 0.88 & 0.51 & 1.39 & 0.45 & 3.74 & 2.12 & 7.94 \\
\hline \multicolumn{10}{|c|}{ Combined (mean seasons) } \\
\hline Pure stands of maize (P3) & 2956.80 & ----- & 1.0 & ----- & 1.0 & 1.0 & ----- & ----- & ----- \\
\hline Pure stands of soybean (P3) & ----- & 1345.58 & ----- & 1.0 & 1.0 & 1.0 & ----- & ----- & ----- \\
\hline$(100 \%$ maize $+50 \%$ soybean on ridges) $(\mathrm{P} 1)$ & 2231.60 & 395.2 & 0.76 & 0.49 & 1.05 & 0.38 & 1.76 & 0.84 & 1.49 \\
\hline$(100 \%$ maize $+50 \%$ soybean on beds) (P2) & 2487.10 & 677.83 & 0.84 & 0.51 & 1.35 & 0.43 & 2.87 & 2.06 & 5.97 \\
\hline
\end{tabular}

\section{Third: Competitive relationship:}

Land equivalent ratio (LER):

Results presented in Table 6 show the effect of intercropping patterns on land equivalent ratio (LER). Land equivalent ratio is a measure of the efficiency of the intercrop. The advantage is measured by the decimal above the unit. In Table 6, however both intercrops showed yield advantages. The least one is that involved intercropping on ridges (1.05 in combined analysis). The best intercropping pattern which involved intercropping on the beds (1.35 in combined analysis).
Interaction effect

Results in Table (6-a) show that when both species were intercropped increased land usage in all combination intercropping patterns in both seasons combined analysis. Intercropping patterns on ridges and beds under tillage depth $15 \mathrm{~cm}$ recorded the highest values for land usage in the combined analysis and increased LER by 18 and $37 \%$, respectively. While, intercropping pattern on ridges and beds under tillage depth $25 \mathrm{~cm}$ gave the lowest values in the pooled data and reached about 13 and $31 \%$, respectively. Similar results were obtained El-Douby et al. (1996), Sahar Sherif et al. (2006) and Fathy et al. (2008).

Land equivalent coefficient (LEC)

Results presented in Table 6 Show the effect of intercropping patterns on land equivalent coefficient (LEC). Land equivalent coefficient is a measure of the efficiency of the intercrop. The advantage is measured by the ratio above the 0.25 . In Table 6 , however both intercrops showed advantages except some intercropping in ridges and combined analysis. The least one is that involved intercropping on ridges $(0.36$ in combined analysis). The best intercropping pattern which involved intercropping on the beds ( 0.43 in combined analysis).

\section{Interaction effect:}

Results presented in Table (6-a) indicated that LEC some achieved yield advantage in combined analysis, where tillage depth at $20 \mathrm{~cm}$ when soybean was planted in ridges $(0.31)$ or in beds $(0.43)$ with maize in the combined which increase than $25 \%$. The highest yield advantage was achieved from tillage at 15 or $20 \mathrm{~cm}$ depth when soybean was grown in beds $(0.43)$ Whereas, the highest values were $(0.31$ and 0.43$)$ in ridges or beds, respectively and the lowest values $(0.22)$ was obtained with tillage at 15 in the combined analysis with intercropping pattern on ridges. 
Relative crowding coefficient (RCC):

In all the treatments, soybean appeared to be highly dominant as it had higher values of $\mathrm{K}$ than the intercrops in different intercropping systems (Table 6). It can be inferred that the intercropped soybean utilized the resources more competitively than maize which appeared to be dominated. As products $(\mathrm{K})$ of coefficients of the component crops were greater than one, there were yield advantage in both the intercropping systems. Results revealed that RCC or K values were more than one in all intercropping patterns in both seasons. Table 6 The least is that soybean and maize involved intercropping on ridges (1.49 in combined analysis). The best intercropping pattern which involved intercropping on the beds (5.97 in combined analysis).

Table 6-a. Land equivalent ration (LER), land equivalent coefficient (LEC), relative crowding coefficient (RCC), as affected by the interaction effect between soil tillage depth and intercropping patterns in both seasons.

\begin{tabular}{|c|c|c|c|c|c|c|c|c|c|c|c|c|c|c|c|c|c|c|}
\hline \multirow{4}{*}{$\begin{array}{l}\text { soil tillage } \\
\text { depth }\end{array}$} & \multicolumn{18}{|c|}{ Intercropping patterns } \\
\hline & \multicolumn{6}{|c|}{ LER } & \multicolumn{6}{|c|}{ LEC } & \multicolumn{6}{|c|}{ RCC } \\
\hline & \multicolumn{3}{|c|}{$\operatorname{Pattern}(\mathbf{P 1})$} & \multicolumn{3}{|c|}{ Pattern(P2) } & \multicolumn{3}{|c|}{ Pattern(P1) } & \multicolumn{3}{|c|}{ Pattern(P2) } & \multicolumn{3}{|c|}{ Pattern(P1) } & \multicolumn{3}{|c|}{ Pattern(P2) } \\
\hline & 2013 & 2014 & comb & 2013 & 2014 & Comb & 2013 & 2014 & comb & 2013 & 2014 & comb & 2013 & 2014 & comb & 2013 & 2014 & con \\
\hline & 0.91 & 1.21 & 1.06 & 1.28 & 1.45 & 1.37 & 0.19 & 0.25 & & 0.39 & 0.47 & 0.43 & 0.66 & 4.83 & 3.00 & 3.60 & 32.79 & 18.20 \\
\hline & 1.02 & 1.10 & 1.06 & 1.29 & 1.39 & 1.34 & 0.39 & 0.24 & & 0.40 & 0.46 & & 1.0 & & & 4.40 & & 5.57 \\
\hline $25 \mathrm{~cm}(\mathrm{D} 3)$ & 0.94 & 1.09 & 1.02 & 1.28 & 1.34 & 1.31 & 0.30 & 0.25 & 0.28 & 0.38 & 0.42 & 0.40 & 0.78 & 1.64 & 1.29 & 3.82 & 5.15 & 4.49 \\
\hline
\end{tabular}

Whereas: Soil tillage depth 15, 20 and $25 \mathrm{~cm}$ (D1, D2 and D3)

Pattern (P1) refers to $100 \%$ maize $+50 \%$ soybean in ridges $(0.70 \mathrm{~m}$ in width) and soybean were intercropped with maize at the other side of the ridge, Pattern (P2) refers to $100 \%$ maize $+50 \%$ soybean in beds $(1.40 \mathrm{~m}$ in width) and maize was intercropped at the both sides of the bed,

Pattern (P3) refers to pure stands of maize and soybean.

\section{Interaction effect:}

Results in Table (6-a) revealed that $\mathrm{RCC}$ or $\mathrm{K}$ values this mean that all intercropping patterns were positive in combined analysis. Intercropping soybean with maize in ridge or beds and procedure tillage system at 15 $\mathrm{cm}$ depth recorded the greatest values for RCC which 18.20 in combined analysis, respectively. Whereas, the lowest values were showed with intercropping pattern in ridge or beds and ploughing depth $25 \mathrm{~cm}$ which were 1.29 and 4.49 in combined analysis, respectively. As well as the

Table 7a. Total income and monetary advantage index (MAI) of maize and soybean as affected by soil tillage depth and intercropping patterns in combined analysis of both seasons.

\begin{tabular}{lcccc}
\multicolumn{4}{c}{ and intercropping patterns in combined analysis of both seasons. } \\
\hline Main effects & $\begin{array}{c}\text { Total income L.E. fad } \\
\text { Income for soybean }\end{array}$ & $\begin{array}{c}\text { Income for maize } \\
\text { income Total }\end{array}$ & MAI L.E. fad $^{\mathbf{- 1}}$ \\
\hline Soil tillage depth & 5690.97 & 3390.46 & 9081.43 & 1324.11 \\
$15 \mathrm{~cm}$ (D1) & 6341.06 & 3672.11 & 10013.17 & 1335.77 \\
$20 \mathrm{~cm}$ (D2) & 5421.23 & 3623.94 & 9045.17 & 1037.08 \\
$25 \mathrm{~cm}$ (D3) & 5052.97 & 1771.49 & 6824.79 & 307.06 \\
Intercropping patterns & 5620.29 & 2886.54 & 8506.83 & 2157.51 \\
Pattern (P1) & 6779.86 & - & 6779.86 & - \\
Pattern (P2) & - & 6028.15 & 6028.15 & - \\
Pattern (P3) maize & & & &
\end{tabular}

clear superiority intercropping pattern in beds on intercropping pattern in ridge. Similar results were obtained by El-Douby et al. (1996), Sahar Sherif et al. (2006) and Lamloum and Ewis (2015).

Fourth: Total income:

Results in Table ( $7 \mathrm{a}$ and $7 \mathrm{~b}$ ) revealed that all intercropping patterns were grown in different depths were positive for total income comparative to maize pure stand in combined analysis of both seasons.

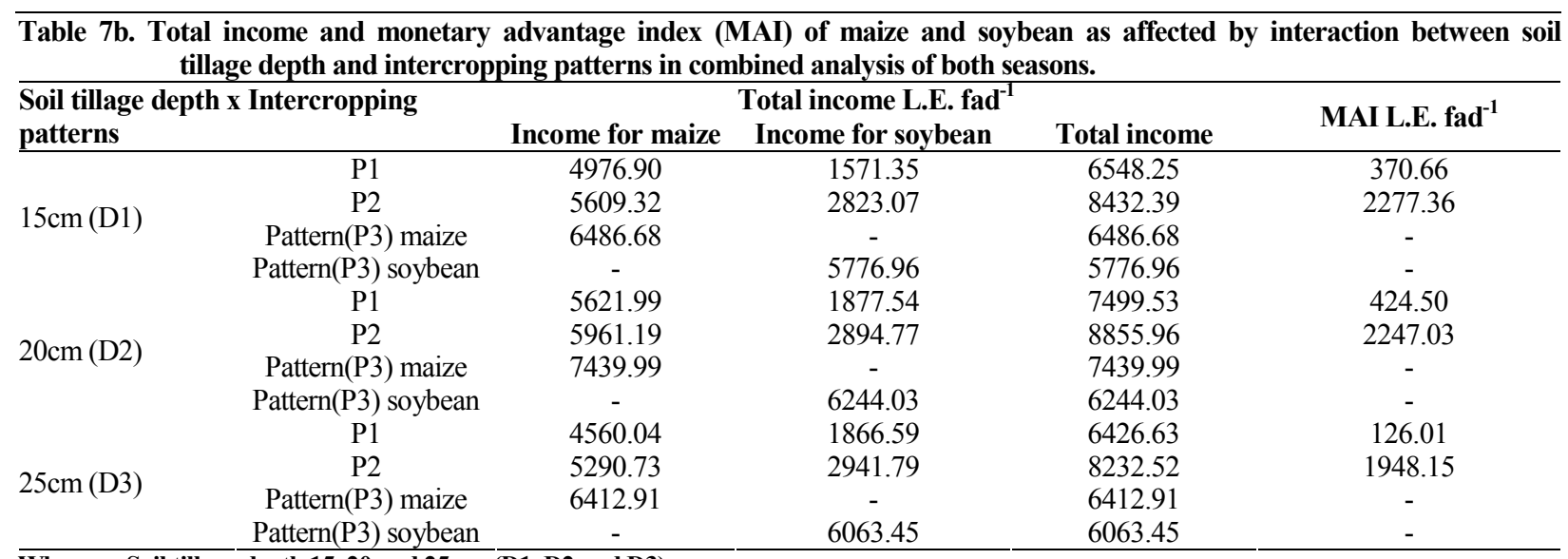

Whereas: Soil tillage depth 15, 20 and $25 \mathrm{~cm}$ (D1, D2 and D3)

Pattern (P1) refers to $100 \%$ maize $+\mathbf{5 0 \%}$ soybean in ridges $(0.70 \mathrm{~m}$ in width) and soybean were intercropped with maize at the other side of the ridge, Pattern (P2) refers to $100 \%$ maize $+50 \%$ soybean in beds $(1.40 \mathrm{~m}$ in width) and maize was intercropped at the both sides of the bed, Pattern (P3) refers to pure stands of maize and soybean. 
The highest total income was achieved with plowing depth at $20 \mathrm{~cm}$ in beds (8855.96 L.E. fad $^{-1}$ ) and the lowest value was showed with plough at $25 \mathrm{~cm}$ in ridge $\left(6426.63\right.$ L.E. fad $\left.^{-1}\right)$. The highest value of intercropping soybean with maize in beds for income and MAI were 8855.96 and 2247.3LE, respectively over than in ridges. Growing maize and soybean with plowing depth at $20 \mathrm{~cm}$ increased total income by 10.26 and $10.70 \%$, while MAI increased by 0.88 and $28.80 \%$ compared with plowing depth 15 and 25 respectively. Similar results were obtained with Lamloum and Ewis (2015). It could be concluded that tillage at $20 \mathrm{~cm}$ depth and intercropping pattern $(100 \%$ maize $+50 \%$ soybean) planted in beds to obtain the best land usage and total income.

\section{REFERENCES}

Abed Al-Karhi, F.D. and A.S. Ali (2014). Effect of tillage and culture systems on growth and yield of sorghum (Sorghum bicolor L.) and Mung bean (Vigna radiate L.) J. Agric. El-Furat Univ., 6 (1):135-143.

Abo-Habaga,M.M.(1992).Influence of soil cods size distribution in seed-bed on the applicability of a grain drill machine for wheat. Misr J.Agric.Eng 9 (1): 58-66.

Aditiloye, P.O., F.O.C. Ezedinma and B.N. Okigbo (1983). A land equivalent coefficient concept for the evaluation of competitive and productive interactions on simple complex mixture. Ecol. Modeling. 19:27-39.

Agricultural Statistics (2013). Economic Affairs Sector, Ministry of Agriculture, Egypt, (in Arabic).

Agricultural Statistics (2014). Economic Affairs Sector, Ministry of Agriculture, Egypt, (in Arabic).

Ahadiyat, Y.R. and S.L. Ranamukhaarachchi (2008). Effect of tillage and intercropping with grass on soil properties and yield of rainfed maize. International J. of Agric. Biol., 10 (2): 133-139.

AL-joburi. J. M. A. and A. A. R. AL-joburi (2015). Evaluation of some genotypes of sorgo (Sorghum bicolor L.) as Genetic sources suitable for different tillage systems. Field Crop Dep. - College of Agriculture - Tikrit Uni. - Iraq.15 (1): 79-89.

De- Wit, C.T. (1960). Intercropping its important and research needs. Part 1. Competition and yield advantages. Verslag Langbov WKundige onderzoek No. 66: 1-82. (C.F. Field Crop Abst. 32, 1-10)]

Dube, E. D. N., T. Madanzi1, A. Kapenzi and E. Masvaya (2014). Root length density in maize/cowpea intercropping under a basin tillage system in a semi-arid area of Zimbabwe. Am. J. of Plant Sciences, 5, 1499-1507

El-Douby, K.A. and S.A. Allam (2001). Effect of intercropping pattern and nitrogen fertilizer level on growth and yield of maize and soybean. J. Agric. Sci. Mansoura Univ., 26 (5): 2593-2609, Egypt.
El-Douby, K.A. (1992). Responses of maize grain yield to different intercropping patterns pp.192-197.ph.D.Thesis, Fac. Agric., Moshtohor, Zagazig univ., Egypt

El-Douby, K.A.; K.E. El-Habbak; H.E. Khalil and Zahira M. Attia (1996). effect of some intercropping patterns on growth and yield of maize and soybean. Ann. of Agric., Moshtohor, 34 (3): 919-933

El-sayed, G.H. (1983). Mechanized techniques for suitable seed bed preparation and planting of maize. M.Sc. Faculty of Agric. Agric. Zagazig Univ. Egypt.

Fathy, A.E., A.A. Ibrahim, A.A.G. Ali, and I.M. Abd EI-Hameed (2008). Yield and yield attributes of soybean and maize as affected by the intercropping with maize. Zagazig $\mathrm{j}$. Agric.Res, 35 (6): 1301-1314

Hussein, A.S., Mahady, A.S., Edan, R.A. and A.A. Reda (2007). Effect of irrigation intervals, plowing depth and planting dates on growth and yield of corn. J. Agric. Karbtaa Univ., 5 (4): 87-98.

Lamloum, M.M. and M.M. Ewis (2015). Effect of some intercropping patterns of soybean with maize on growth, yield and yield component and water use efficiency. Egypt. J. Agric. Res., 93 (2 A): 53-69

Monzon, J.P., J.L. Mercau, J.F. Andrade, O.P. Caviglia, A.G. Cerrudo, A.G. Cirilo, and P.A. Calvio (2014). Maizesoybean intensification alternatives for the Pampas. Field Crops Res, 162, 48-59.

Sahar Sherif. A, Wafae Mohamed K.h., Sahar Ibrahim T., H.E. Osman and S.I. EL-Khatib (2006). Effect of tillage treatments and intercropping patterns on water use efficiency and yield components of soybean and maize. Arab Univ. J. Agric. Sci., Ain Shams Univ, Cairo, 14 (1): 173-193.

Sherif, M.N.:S.K. Badr and A.M. Alx y (1995). Effect of some preceding winter crops and tillage on growth, yield and quality of maize. Egypt.J.Appl Sci., 10 (12):127-138.

Steel, R.G.D.; J.H.Torrie and Dicky D.A. (1997). Principles and procedures of statistics, a biological Approach. $3^{\text {rd }} \mathrm{Ed}$. MacGraw Hill Book Co. New Yourk. 172-177.

Thierfelder C, Cheesman S, L. Rusinamhodzi (2012). A comparative analysis of conservation agriculture systems: Benefits and challenges of rotations and intercropping in Zimbabwe. Field Crops Res. 137: 237-250.

Willey, R.W. (1979). Intercropping-its importance and research needs. Part 1. Competition and yield advantages. Field Crop Abstr. 32, 1-10.

Wu KX, and Wu BZ (2014). Potential environmental benefits of intercropping annual with leguminous perennial crops in Chinese agriculture. Agric Ecosystems and Environment 188: 147-149.

Yugi R. Ahadiyat, and Senaratne L. Ranamukhaarachchi (2011). Different tillage and maize grass intercropping on root systems, growth and yield of rainfad maize (Zea mays L.) AAB Bioflux, 3 (1): 33-39.

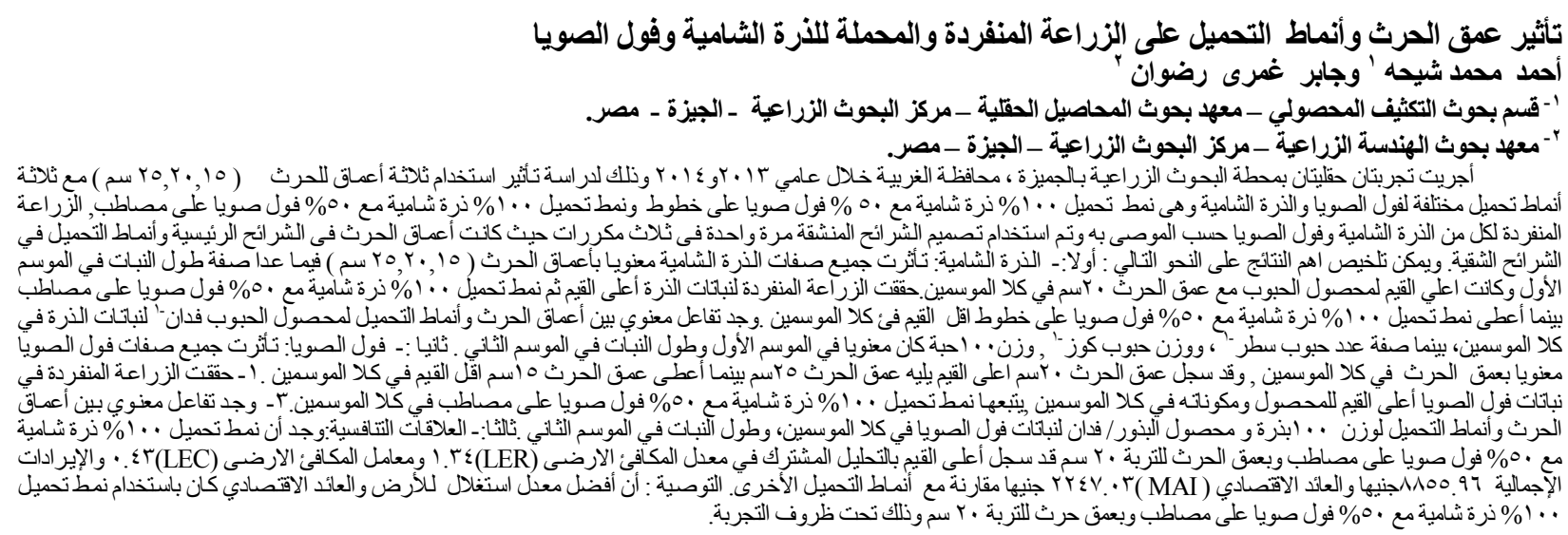

